\title{
The Impact of the COVID-19 Pandemic: The Case of Remittance Recipient Countries ${ }^{1}$
}

\author{
K. Bondarenko
}

Ksenia Bondarenko - Economist, Global Markets Research, ANCOR Hi-Tech, LLC; 19 Leninskaya Sloboda Ulitsa, Moscow, 115280, Russian Federation; Visiting scholar, PhD student, School of World Economy, National Research University Higher School of Economics; 20 Myasnitskaya Ulitsa, Moscow, 101000, Russian Federation; E-mail: xenabondarenko@gmail.com

\begin{abstract}
The advent of the new coronavirus hinders the fragile welfare of migrant workers. Those economic sectors with a large migrant workforce appear to be those hit hardest during the lockdown, resulting in surge in migrant unemployment and a plunge in the volume of remittances. This has become yet another factor putting pressure on the gross domestic product (GDP) growth, balance of payments, and budgets of countries that are net remittance recipients, while also triggering rising poverty levels.

This paper evaluates the impact of the current pandemic (and respective economic downturn) on remittance inflows to recipient countries and tackles the potential contribution that international financial institutions could make to alleviate the adverse economic aftermath. In Central Asia and Southern Caucuses (except Azerbaijan) emergency financing granted by the International Monetary Fund (IMF) and the World Bank covers 9-20\% of the overall size of the annual remittances received. This financial support could be rendered insufficient due to the sharp decrease in the volume of remittances, decline in tourism revenue, and weakening economic activity, while the poor quality of state institutions may hinder the efficient distribution of accumulated resources.

In Europe, the IMF and the World Bank provided approximately \$7.7 billion in financing to low- and middleincome countries for such purposes as economic stabilization, support for population welfare, and financing of internal/external deficit, of which \$5 billion is represented by the new Ukraine-IMF Stand-By Agreement. With the exception of Ukraine, Macedonia, and Bulgaria (the latter having received no loans/grants so far), the cover index for European remittance-recipients stands within a range of 2-18\% over 2019 remittance inflows.

Therefore, it is most feasible that the current 2020 GDP growth forecasts made by the IMF, the World Bank, and local governments are inaccurate in the light of the insufficient financial support provided by international financial organizations. Additional pressure on the GDPfigures might stem from further extension and/or toughening of the lockdown period, as well as from uncertainty regarding the revival of regular business activity and the timeline for resuming migrant remittances.
\end{abstract}

Key words: migration; remittances; macroeconomics; coronavirus; foreign aid; EAEU; Uzbekistan; Europe

For citation: Bondarenko K. (2020) The Impact of the COVID-19 Pandemic: The Case of Remittance Recipient Countries. International Organisations Research Journal, vol. 15, no 3, pp. 109-128 (in English). DOI: $10.17323 / 1996-7845-2020-03-04$

\section{Introduction}

The spread of the new coronavirus infection led to a global recession in 2020 [Grigoryev, Pavlyushina, Muzychenko, 2020]. Significant discrepancies in the data coming from different

${ }^{1}$ The author would like to thank Dr. Leonid Grigoryev, Dr. Marina Larionova, Dr. Maksim Rudakov and the editors of "International Organisations Research Journal" for their comments, advice and support. 
countries regarding the COVID-19 contamination statistics call into question data quality, thus making it possible that the actual spread of the disease is much broader [Duarte et al., 2020]. In May 2020, certain countries decided to ease lockdown measures. However, some countries and a number of U.S. states appear to have withdrawn measures too fast, leading to new outbreaks in June and July. It is therefore too early to make predictions regarding the passing of the peak of the pandemic.

There is a significant level of uncertainty regarding the impact of COVID-19 on economic activity [Barro, Ursúa, Weng, 2020] since preliminary indications show that the global gross domestic product (GDP) may lose \$2-4.1 trillion [Abiad et al., 2020; ADB, 2020a]. However, the actual figures may be well above this level. International financial institutions (the International Monetary Fund (IMF), the World Bank) and other international organizations and funds [Vinokurov, Levenkov, Vasiliev, 2020] including the Eurasian Development Bank (EDB), the Asian Development Bank (ADB), the European Bank for Reconstruction and Development (EBRD) and others allocate financial support to low- and middle-income countries. Nevertheless, this support can only curb an economic downturn temporarily. The closing of international borders and business lockdowns led to a deterioration of global supply chains and a decrease in global manufacturing and demand resulting in plummeting requirements for migrant labour [Adams-Prassl et al., 2020]. Rising unemployment is the most obvious global sign of this process [CCSA, 2020], accompanied by decline in real income [Kartseva, Kuznetsova, 2020].

Labour migrants turned out to be the most vulnerable strata [Cohen, 2020], as their potential losses during recession are generally much higher compared with those of the endemic populations [Varshaver, 2020]. The current crisis may have a much more significant adverse impact on labour migrants (compared with 2008-09) given that the affected industries have high concentrations of migrant workers: tourism (accommodation business and ancillary services), public catering, wholesale and retail, transportation and logistics, construction and manufacturing, as well as agriculture [Kartseva, Kuznetsova, 2020; UN, 2020]. Research conducted by the KNOMAD and the International Labour Organization (ILO) [2016] regarding the Russian market showed that at least $27 \%$ of migrants work in construction, $18 \%$ in retail and $7 \%$ in public catering. For highly qualified migrants the subdivisions are as follows: $35.4 \%$ in wholesale and retail, $12.4 \%$ in construction, $10.3 \%$ in municipal services, $7.4 \%$ in accommodation and hospitality and $7.8 \%$ in transportation, logistics and communication [Mukomel, 2020].

After the closing of borders and bans on international transportation [IOM, 2020] only a fraction of labour migrants moved to their home countries - in most cases, when the labour exporting and importing countries had either a common border (Uzbekistan/Kazakhstan, Ukraine/Poland, Venezuela/Colombia [MMC, 2020]) or tailored charter flights arranged with state support that allowed direct evacuation of migrants from the recipient country. Most labour migrants remained in the recipient country rather than be exposed to rising unemployment at home, while those who struggled to return (due to loss of job) were physically unable to do so. ${ }^{2}$

The sharp decline in migrant flows and bounding unemployment resulted in significant decrease in remittances starting from March 2020 (considering data available from the balance of payments and comments provided by the central banks of the labour exporting ${ }^{3}$ and labour importing 4 countries). The World Bank preliminarily forecasts the decline in 2020 remittances to reach $19.9 \%$ year-over-year (YoY) from the record of $\$ 714$ billion in 2019 to $\$ 572$ billion in

\footnotetext{
${ }^{2}$ Migrants waited months for flights to return home. See A. Sokolov [2020]

${ }^{3}$ For example, Ukraine and Uzbekistan.

${ }^{4}$ For example, Russia.
} 
2020 (Table 1) which would have a negative impact on the macroeconomic performance of the recipient countries [Chepel, Bondarenko, 2015].

Countries with low and middle incomes may experience up to a $19.7 \%$ YoY decline in the volume of remittances, with the deepest decline forecasted for the European and Central Asian countries (27.5\% YoY). These figures, however, may be subject to reconsideration due to uncertainty regarding the quantitative evaluation of COVID-19's impact on the economic recession. Among the key reasons for this are the cancellation of the tourist season in Europe, a much sharper decline in the economic activity in the European Union (EU) (which is critical for Ukraine and Moldova), an extension of the lockdown in Russia until the end of June (for Eurasian Economic Union (EAEU) countries [Grigoryev, Brilliantova, Pavlyushina, 2018], Uzbekistan and Tajikistan), as well as the re-introduction of lockdown measures in a number of countries in the region, including Kazakhstan (a net importer of migrants) and Uzbekistan (a net exporter of migrants).

Table 1. Subdivision of Remittances (\$ Billions), 2009-21

\begin{tabular}{|l|c|c|c|c|c|c|c|}
\hline \multicolumn{1}{|c|}{ Region } & $\mathbf{2 0 0 9}$ & $\mathbf{2 0 1 6}$ & $\mathbf{2 0 1 7}$ & $\mathbf{2 0 1 8}$ & $\mathbf{2 0 1 9}^{\mathrm{e}}$ & $\mathbf{2 0 2 0}^{\mathrm{f}}$ & $\mathbf{2 0 2 1}^{\mathbf{f}}$ \\
\hline World, \% YoY & -5.1 & -0.9 & $7.7 \%$ & $8.0 \%$ & $2.8 \%$ & $-19.9 \%$ & $5.2 \%$ \\
\hline World & 437 & 597 & 643 & 694 & 714 & 572 & 602 \\
\hline $\begin{array}{l}\text { Low- and middle-income countries, } \\
\text { including: }\end{array}$ & 307 & 446 & 487 & 531 & 554 & 445 & 470 \\
\hline East Asia and Pacific & 80 & 128 & 134 & 143 & 147 & 128 & 138 \\
\hline Europe and Central Asia & & & & & & & \\
\hline Latin America and the Caribbean & 55 & 73 & 81 & 89 & 96 & 77 & 82 \\
\hline MENA & 33 & 51 & 57 & 58 & 59 & 47 & 48 \\
\hline Southern Asia & 75 & 111 & 118 & 132 & 140 & 109 & 115 \\
\hline Sub-Saharan Africa & 29 & 39 & 42 & 48 & 48 & 37 & 38 \\
\hline
\end{tabular}

Notes. $2019 \mathrm{e}$ - estimate; $2020^{\mathrm{f}}, 2021^{\mathrm{f}}-$ forecast

* World bank classification (2020) treats the following 21 countries as "low- and middle-income": Azerbaijan, Albania, Armenia, Belarus, Bulgaria, Bosnia and Herzegovina, Georgia, Kazakhstan, Kosovo, Kyrgystan, Macedonia, Moldova, Russia, Romania, Serbia, Turkey, Tadjikistan, Turkmenistan, Uzbekistan, Ukraine, Montenegro.

Source: [World Bank, 2020a].

Turkmenistan is excluded from further analysis due to the absence of valid statistics regarding the size of remittances and migration. Seventeen out of the remaining 20 countries are net remittance recipients, while only three are net senders (Fig. 1).

The latter are: Turkey, an unprecedented case of transformation from net recipient into net sender in 2017; Kazakhstan, the only net sender of remittances in Central Asia; and Russia, which acts as the key sender of remittances for Central Asian and Caucasian countries while ranking second as a remittance recipient among its low- and middle-income peers (after Ukraine). 


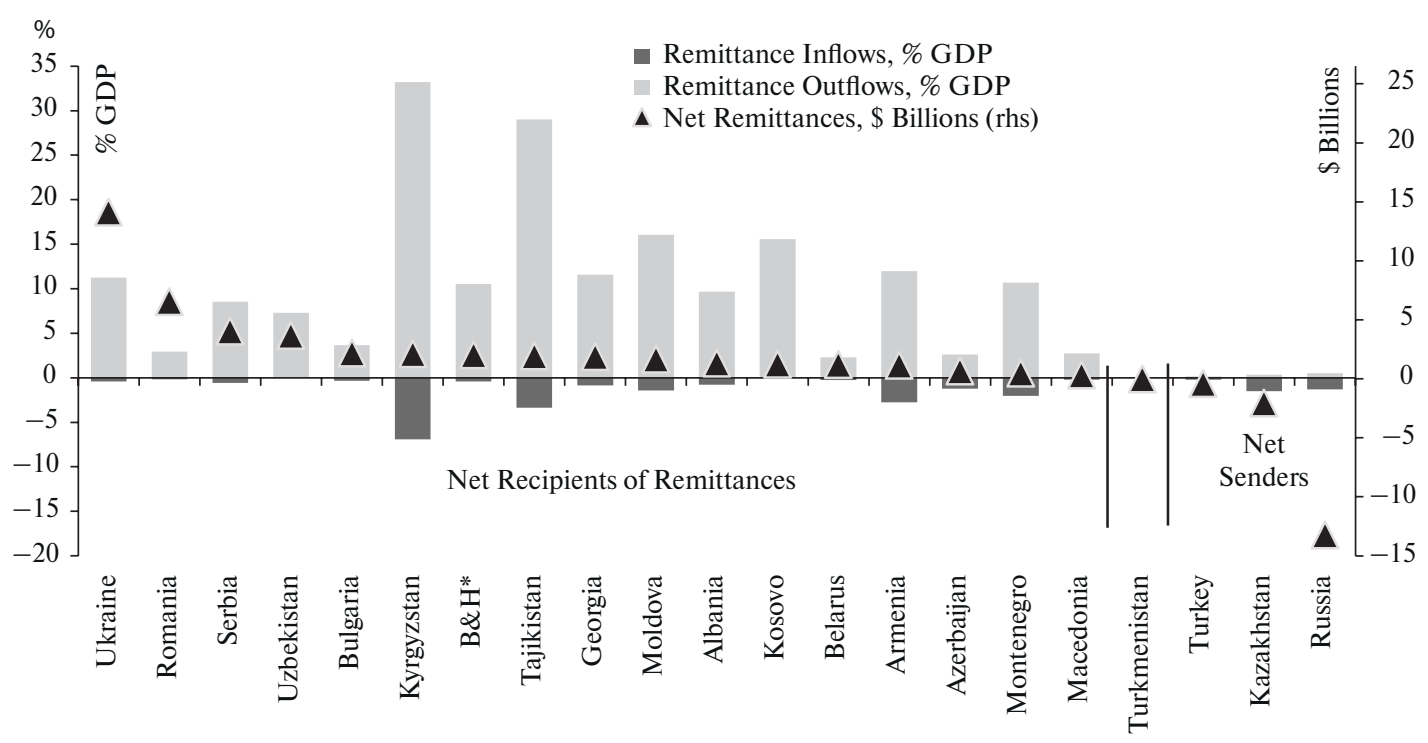

Fig. 1. Senders and Recipients of Remittances, 2018

Note. *Bosnia and Herzegovina.

Source: [World Bank, 2020i].

It is evident that it will be only through direct support from international organizations (such as the World Bank, the IMF, the EBRD, the ADB and others) on top of the efforts of local governments that Central Asian and European countries can stem the negative effect from COVID- $19 .{ }^{5}$

\section{COVID-19 Pandemic and Recession in Russia}

The bilateral remittance matrix [World Bank, 2019c] indicates that the overall volume of remittances sent to Armenia, Azerbaijan, Georgia, Kyrgyzstan, Tajikistan and Uzbekistan totalled $\$ 21.8$ billion in 2018 .

The COVID-19 pandemic had a negative impact on both the internal and external sectors of the Russian economy, and by March 2020, producers' economic activity had already started to weaken: for example, industrial production grew [Federal State Statistics Service of Russia, 2020 ] only by $0.3 \%$ YoY in March 2020, while construction growth was capped by a negligible $0.1 \%$ YoY.

The lockdown introduced in Q2 2020 saw a decrease in the level of retail sales $(-16.6 \%$ YoY) and industrial production ( $-8.5 \%$ YoY). Many migrants, previously employed in the retail, servicing, and some construction companies lost their jobs, ${ }^{6}$ while declines in disposable household income (by $0.2 \%$ YoY in the first quarter of 2020 and by $8.0 \%$ YoY in the second

${ }^{5}$ This study focuses on financial support from international organizations (the World Bank, the IMF, etc.) that aims to mitigate the consequences of the pandemic. Their other projects (e.g. in the field of agriculture and/or education) are not included in the research.

${ }^{6}$ As per the Ministry of Internal Affairs, 33\% of labour migrants work in retail and wholesale trade, $16 \%$ in the construction sector, $14 \%$ in transport, logistics and communications, and $15 \%$ in the accommodation and hospitality sphere. No data is available for the remaining numbers of migrants. 
quarter) had a negative impact on the well-being of CIS + national diasporas. The Bank of Russia [2020] shows that the average size of a single cross-border remittance dropped from $\$ 413$ (in Q2 2019) to \$230 (in Q2 2020) that was aggravated by the devaluation of the Russian rouble in March 2020.

All of the above factors pushed the average annualized remittance size further down in Q2 2020 by $28.0 \%$ YoY in roubles and $35.7 \%$ YoY in dollars. Since many seasonally employed migrants this year are unable to work due to the extension of quarantine measures, further deterioration by the end of 2020 is expected.

\section{Central Asia}

The size of remittances received by Kyrgyzstan (a member of the EAEU), Tajikistan and Uzbekistan in 2019 totalled $\$ 8.9$ billion (of which Russia, as sender, accounted for roughly $\$ 7$ billion). These Central Asian countries are characterized by relatively high economic growth rates; even during the period of the 2008-09 crisis GDP dynamics remained positive, largely due to the high influx of external remittances [O'Hara, Ivlevs, Gentile, 2009], which were the cornerstone of domestic consumption [Brownbridge, Canagarajah, 2010]. It is notable that during the 2009 crisis remittances decreased by $29 \%$ in annualized dollar terms, while during the 2015 economic downturn in Russia it plummeted by $38 \%$ (Fig. 2).

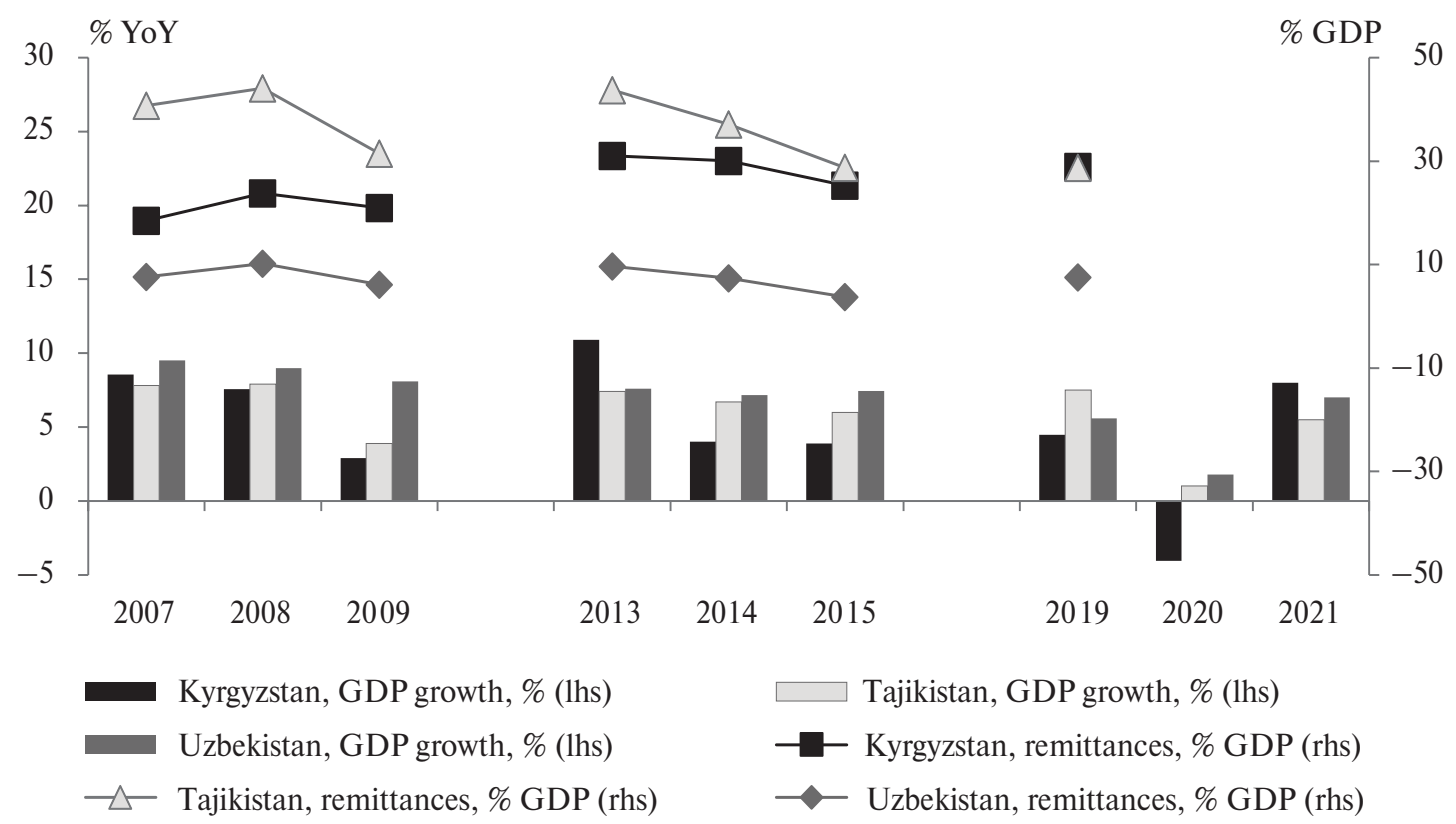

Fig. 2. Economic Growth (\%, YoY) and the Size of Remittances (as \% of GDP) Received by the Central Asian Countries

Source: [IMF, 2020a].

The situation is much different during the current COVID-19 crisis: in combination, the massive lockdown, decrease in exports, economic recession, devaluation of the Russian rouble and massive unemployment among the migrant community may cause the overall remittance of migrants toward Kyrgyzstan, Uzbekistan and Tajikistan to drop 50\% in 2020. The latter trend 
might become a hefty factor (and much more important than initially assumed) with a negative impact on GDP dynamics and balance of payments in the Central Asian countries, resulting in rising poverty levels.

Uzbekistan ranks first in the Central Asian region in terms of the absolute volumes of remittances received, with $\$ 4.2$ billion in 2019 (7.5\% of GDP), although this estimation may be conservative due to the poor quality of statistical data in the country [IMF, 2018]. For example, the Bank of Russia and the Central Bank of Kazakhstan report that the total size of private transfers from these two countries to Uzbekistan reached $\$ 4.5$ billion (in nominal terms) in 2019, thus testifying to the fact that the actual share of remittances in Uzbekistan's GDP might end up being $10-15 \%,{ }^{7}$ almost twice as much as officially stated. The growing volume of remittances was one of the key drivers for poverty reduction: in 2013, remittances to Uzbekistan represented $7 \%$ of household income in the lower $40 \%$ of the income distribution strata and up to $12 \%$ in the upper 60\% [World Bank, 2019b], while in 2019 even the official data showed that the share of external remittances from labour migrants had climbed to $15 \%$ of household income [Ministry of Economic Development and Poverty Reduction of the Republic of Uzbekistan, 2019; State Committee of the Republic of Uzbekistan on Statistics, n. d.].

The Central Bank of Uzbekistan [2020b] reported that the size of remittances decreased by only 6\% YoY in January - June 2020 (including a 11.3\% YoY drop in Q2 2020). The regulator expects the volume of remittances to fall by $30-5 \%$ as of 2020 year-end [CBU, 2020]. However, this estimate may appear underrated due to the prolonged lockdown in Russia and the re-introduction of lockdown measures in Uzbekistan [Reuters, 2020] (including the closing of borders and mandatory isolation periods for all inbound passengers/visitors) which could lead to a sharper decrease in household consumption levels (middle-class in particular) and a rise of poverty.

The IMF provided a $\$ 375$ million $^{8}$ soft loan to Uzbekistan, while the World Bank granted \$38 million to strengthen the national healthcare system, an additional \$57 million as target financing to support poor and most financially vulnerable parts of society suffering from the COVID-19 outbreak [World Bank, 2020d], and approved a \$200 million loan to mitigate the aftermath of the lockdown measures [World Bank, n. d.]. The Asian Development Bank (ABD) in its turn provided Uzbekistan with a grant [ADB, 2020b] to purchase medical equipment as well as reallocated $\$ 19.5$ million out of the existing credit line for purchasing 800 artificial lung ventilation machines.

Uzbekistan plans to borrow up to $\$ 3.1$ billion (5.6\% of GDP) to mitigate the consequences of the lockdown and to improve the national healthcare system [President of the Republic of Uzbekistan, 2020]. Nevertheless, the provided financing would be unlikely to lead to dramatic improvement of the current challenges faced by Uzbekistan due to its weak internal economic activity and the targeted nature of the external help. Thus, the IMF's forecast for a $1.8 \%$ decrease in Uzbekistan's GDP might turn out to be overly optimistic.

Official figures indicate that the overall volume of remittances to Kyrgyzstan in 2019 reached $\$ 2.4$ billion, representing 28.9\% of GDP [World Bank, 2019a]. The Central Bank of Kyrgyzstan [NBKR, 2020] reported that the size of remittances had dwindled by more than 26\% YoY in January - May 2020; that, accompanied by the decrease in proceeds from tourism,

${ }^{7}$ According to B. Tursunov, the head of the Agency for External Labor Migration at the Ministry of Employment and Labor Relations of Uzbekistan [Gazeta, 2019]. See also G. Turrisi [2020].

${ }^{8}$ Hereinafter, unless otherwise stated, IMF [2020b].

${ }^{9}$ Hereinafter, we use the IMF forecasts from World Economic Outlook in April, since the updated version in June did not include most of the countries under our research. IMF Regional Economic Outlook Update: Middle East and Central Asia (June) forecasts are aggregated (i.e., for oil and gas exporting countries in Central Asia). 
may not only boost poverty levels but could also lead to widening the already quite large deficit of the balance of payments.

The country's budget would also be deficit-ridden in 2020, being partially covered by a $\$ 40$ million IMF tranche, the latter having provided two grants to Kyrgyzstan in March and May in the amount of $\$ 120.9$ million and $\$ 121.1$ million respectively. Backed by the Paris Club and G20, the country's government requested a temporary moratorium on debt servicing with the intention to utilize freed-up funds to finance the national healthcare system and mitigate consequences of COVID-19. The World Bank [2020e] provided Kyrgyzstan with \$12.15 million and an additional $\$ 9$ million to mitigate the aftermath of the pandemic. The ADB will allocate a tranche of $\$ 120$ million [ADB, 2020c] within the "Central Asia Regional Economic Cooperation" programme (CAREC), with $50 \%$ of the tranche being unrequited. Considering additional grants received from the EU, the German Society for International Cooperation (GIZ) and other donors, the size of financial support would reach $\$ 1$ billion or $12 \%$ of GDP; that would be instrumental in stemming the size of the upcoming recession but will not prevent it from happening.

The volume of remittances directed to Tajikistan in 2019 reached $\$ 2.3$ billion (or $28.7 \%$ of GDP), although the actual size might be much greater. In 2014-16, the volume of remittances from Russia plummeted from almost 44\% of GDP in 2013 to $27 \%$ of GDP in 2016 due to recession in Russia, and that became one of the key factors for the slowdown of Tajikistan economy. Nevertheless, for the last three years Tajikistan has seen rising economic growth figures driven by growing internal consumption supported by rising remittances and accelerated state spending and investments [World Bank, 2019a].

A study conducted by the Scientific Research Institute of the National Bank of Tajikistan [Bakozoda, 2019] showed that as much as $70 \%$ of the population in the country has to rely on remittances from migrants. Hence the reduction of these remittances in 2020 will have a negative impact on consumption levels and would most likely lead to an economic slowdown, a rise in poverty and, finally, might even become a factor of social and economic turmoil.

The local government attempts to support disadvantaged groups by allocating additional budget funding, covered by the $\$ 189.5$ million IMF credit line. Considering grants provided by the World Bank and the ABD, the total financial relief can be estimated at 2-3\% of GDP.

Table 2. COVID-19 Emergency Financing by the IMF and the World Bank and Personal Remittances Received in Central Asia, \$ Millions*

\begin{tabular}{|l|c|c|c|c|}
\hline \multirow{2}{*}{ Country } & \multicolumn{2}{|c|}{ Total Financing, 2020 } & Remittances, 2019 & Cover Ratio, \%** \\
\cline { 2 - 5 } & IMF & World Bank & & \\
\hline Uzbekistan & 375 & 295 & 4150 & 16.1 \\
\hline Kyrgyzstan & 242 & 21 & 2410 & 10.9 \\
\hline Tajikistan & 190 & 11 & 2298 & 8.7 \\
\hline
\end{tabular}

Notes. * As of 31 July $2020,{ }^{* *}$ The cover ratio is the ratio between the volume of grants provided and the level of remittances, $\%$.

Source: [IMF, 2020b; World Bank, 2020c; author's estimates].

Grants provided by the IMF and the World Bank to the Central Asian countries covered $9-16 \%$ of the overall size of remittances (Table 2), which might prove insufficient considering 
the anticipated decline (by 30-50\%) in the size of remittances in $2020 .{ }^{10}$ The second important issue is the inefficiency of the rule of law in Uzbekistan, Kyrgyzstan and Tajikistan that may result in the ineffective allocation of the granted financial resources.

\section{Southern Caucasus}

Two out of three Transcaucasian countries - Georgia and Armenia - heavily depend on external remittances: for example, the share of remittances to GDP in 2019 was above $11 \%$ in both cases.

The total volume of remittances sent to Georgia in 2019 reached $\$ 2.3$ billion, while remittances to Georgian households fell by 5\% YoY in January - June 2020 [NBG, 2020]. Though there was a rise in the volume of remittances in January - February 2020 vs January - February 2019, their size dropped by 20\% YoY in March - May. June saw another rebound with lockdown easing in developed countries (i.e. Italy, Greece, Germany and the U.S.) and an influx of "postponed" remittances that partially compensated for the drop in the spring. Nevertheless, the total volume of remittances from Russia continued sliding throughout 2020, aggravated by the recession. This accounts for the broadened geography of labour migration and a higher "diversification of origin" for remittances. Georgia has recently faced rising volumes of remittances from the EU (Italy and Greece) and the U.S., although Russia still ranks first as an immigration destination and source of international transfers (more than $32 \%$ as of June 2020) [Grigoryev et al., 2019]. The pandemic has had a negative impact on the key revenue components of Georgian GDP (export, largely agricultural, tourism and investments). However, the Georgian economy is distinguished from its neighbours due to the much higher importance of tourism: the slide in tourist revenue since July 2019 resulted in a monthly loss of $\$ 622$ million (or 3\% of GDP) [Ibid.], and the adverse effects of the current crisis will most likely worsen the situation.

The IMF and the World Bank [2020f] provided Georgia with \$375.6 million and 80 million euros, respectively, as financial aid to finance the current budget deficit. In addition, Georgia also received 150 million euros under the EU's Eastern Partnership programme. Though the Georgian government expects to receive $\$ 1.5$ billion (or $7.5 \%$ of GDP) in financial support from international organizations, these volumes might prove insufficient to prevent a recession, so the actual 2020 GDP drop may turn out to be higher than the $4 \%$ hurdle envisaged by the IMF.

The Armenian GDP is likely to drop by $1-2 \%$ YoY in 2020 . The COVID-19 pandemic had a negative impact on the construction and tourism sectors, as well as industrial manufacturing (some of the segments were put to a halt). These issues, accompanied by the inability of labour migrants to reach destination countries, might lead to a surge in unemployment (which already is quite significant). The number of unemployed may surge by 40,000 people, with the unemployment rate accelerating from $17.7 \%$ to $19 \%$ [Arka News Agency, 2020]. However, considering the fact that more than 200,000 Armenians used to travel to Russia as seasonal workers in the past years [Manasserian, 2019], the actual rise in unemployment might be much higher.

To neutralize the adverse effects of the pandemic, the IMF expanded the Stand-by-Arrangement loan agreement signed in 2019 for Armenia by another $\$ 175$ million, while the World Bank allocated \$3 million [World Bank, 2020g].

The economy of Azerbaijan does not depend on remittances (the latter constituting roughly $1.9 \%$ of the country's GDP). However, per the IMF forecast, the Azerbaijani GDP might drop

${ }^{10}$ At the same time, some countries (see above) receive funding from other international organizations; however, most of these grants were at the discussion stage as of 31 July. 
to $2.2 \%$ YoY amid declining export revenues (triggered by low oil prices), falling tourism revenues and low investment growth. The above estimation did not take into account the OPEC + deal under which Azerbaijan would need to cut its oil production by $23 \%$ in May - June and by $18 \%$ going forward until the 2020 year-end. A much sharper GDP drop might occur amid high dependence of the Azerbaijani economy on the oil and gas sector, which accounts for $7 \%$ of GDP and $86 \%$ of exports.

Nevertheless, Azerbaijan remains the only country in the region that did not turn to the international organizations for financial support (Table 3).

Table 3. COVID-19 Emergency Financing by the IMF and the World Bank and Personal Remittances Received in the South Caucasus, \$ Millions*

\begin{tabular}{|l|c|c|c|c|}
\hline \multirow{2}{*}{ Country } & \multicolumn{2}{|c|}{ Total Financing, 2020 } & \multirow{2}{*}{ Remittances, 2019 } & Cover Ratio, \% \\
\cline { 2 - 3 } & IMF & World Bank & & \\
\hline Georgia & 376 & 80 & 2258 & 20.2 \\
\hline Armenia & 175 & 3 & 1528 & 11.6 \\
\hline Azerbaijan & - & - & 1077 & - \\
\hline
\end{tabular}

Note. * As of 31 July 2020.

Source: [IMF, 2020b; World Bank, 2020c; author's estimates].

The cover ratio for the IMF and the World bank (without taking into account grants provided by other international financial organizations ${ }^{11}$ ) stands at more than $20 \%$ for Georgia and almost $12 \%$ for Armenia. To finance budget spending (roughly $4.3 \%$ of GDP) Azerbaijan uses its own financial reserves, which remain high (the State Oil Fund's assets and Central Bank reserves stood in total at $100 \%$ of GDP as of 1 July 2020), notwithstanding the necessity to support the national currency.

\section{Eastern and South-Eastern Europe}

The 11 European countries ${ }^{12}$ of the current sampling accounted for $61 \%$ of the total volume of remittances received in 2019 (\$39.4 billion, of which \$29.5 billion goes to Ukraine, Romania, Serbia and Bulgaria).

Ukraine has ranked first as the receiver of remittances in nominal terms for the last five years, with $\$ 15.8$ billion in transfers in 2019 alone [World Bank, 2020]. ${ }^{13}$ The continuous growth in the number of labour migrants leaving Ukraine results in the rising importance of remittances to the national economy: the share of transfers more than doubled from $5.5 \%$ in 2014 to $11.3 \%$ in 2019 (Fig. 3).

Following the COVID-19 lockdown this year at least $10 \%$ of labour migrants have already returned to Ukraine; that immediately led to decreasing annualized volumes of remittances. With

\footnotetext{
$66 \%$.

${ }^{11}$ Taking into account the planned volume of external borrowings this year, this ratio in Georgia exceeds

${ }^{12}$ European countries include: Albania, Belarus, Bosnia and Herzegovina, Bulgaria, Kosovo, Moldova, Montenegro, North Macedonia, Romania, Serbia and Ukraine.

${ }^{13}$ According to the Central Bank of Ukraine, the volume of cash transfers amounted to $\$ 12.0$ billion in 2019. The differences in estimates are due to variations in methodology.
} 
the lockdown in Russia (a key importer of Ukrainian labour migrants ${ }^{14}$ ), the U.S. and the EU, the non-feasibility of seasonal migration, and anticipation of slow recovery of demand for labour due to the U-shaped or even Lj-shaped [Grigoryev, Pavlyushina, Muzychenko, 2020] nature of the recession, the volume of remittances slumped by 9.5\% YoY in January - June 2020, with figures not turning positive before the year-end. As a result, the global pandemic may cause remittances to decrease by \$2-3 billion in 2020; that would cost the Ukrainian economy at least 2\% of GDP. Consumption accounts for roughly $70 \%$ of the Ukrainian GDP so the lockdown measures and drop in transfers may lead to a GDP slump of higher than $7.7 \%$, which is the current IMF forecast.

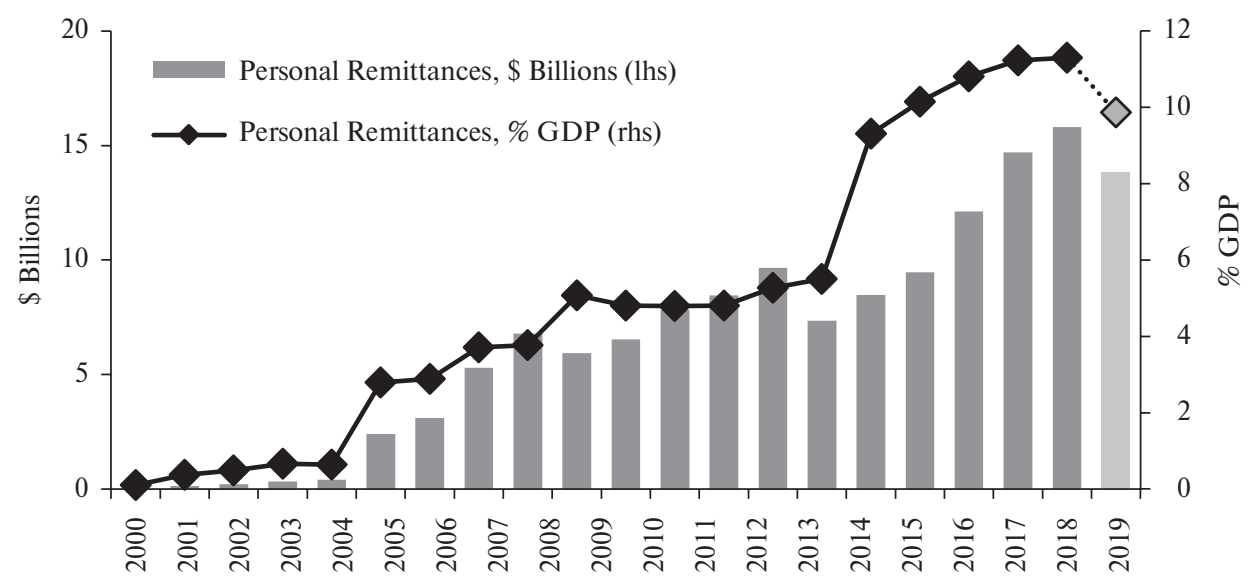

Fig. 3. Remittance Inflows in Ukraine, 2000-20

Source: [World Bank, 2020i; author's estimates].

The national economy of Moldova is destined to take a significant blow from the pandemic notwithstanding the fact that the share of remittances has dropped by $50 \%$ during the last 14 years (from 34\% in 2006 to $15.9 \%$ in 2019). Moldova's internal consumption and economic growth still heavily depend on remittances [Ito, 2017]. Kosovo might experience a similar situation: the share of remittances to GDP there was $15.2 \%$ in 2019.

Three other European countries (Romania, Bulgaria and Belarus) account for $\$ 11$ billion worth of remittances; however their dependence on the latter remains low as they represent only $2-3 \%$ of GDP. The EU countries and the U.S. represent the largest senders of remittances to Romania and Bulgaria, with Russia being the key source of transfers for Belarus. Thus, the decline in remittances would not play a significant role in their economic development, unlike in Ukraine, Moldova and Kosovo. The downturn in Romania, Bulgaria and Belarus would largely be triggered by internal factors, such as a drop in consumption (which is acute even in Belarus, although the government decided to avoid lockdown measures) and a decrease in investments.

The Balkan countries (Montenegro, Serbia, Albania, Kosovo, Macedonia, and Bosnia and Herzegovina) are characterized by the crucial role that remittances play not only in GDP growth, but also in balance of payments (Fig. 4).

In 2019 Montenegro ranked first among the countries with a low- or medium-development level in terms of the share of remittance in GDP at $26.4 \%$ ( $\$ 1.4$ billion). The volume of transfers exceeded its 2018 numbers by 2.3 times, which is (most likely) due to methodological adjustments introduced after the IMF completed its 2019 Article IV consultation with Monte-

${ }^{14}$ According to the bilateral remittance matrix [World Bank, 2019c]. 
negro and advised a revision of the methodology for recording data on remittances given high levels of cash inflows [IMF, 2019].

While Montenegro has largely overcome data quality issues, Macedonia still has much to do in this field. Official data shows that the level of remittances in 2019 reached $2.5 \%$ of GDP. However, the actual figure would reach as high as $13.6 \%$ should one adjust the official data with private transfers received by the citizens from unofficial sources [World Bank, 2020b].
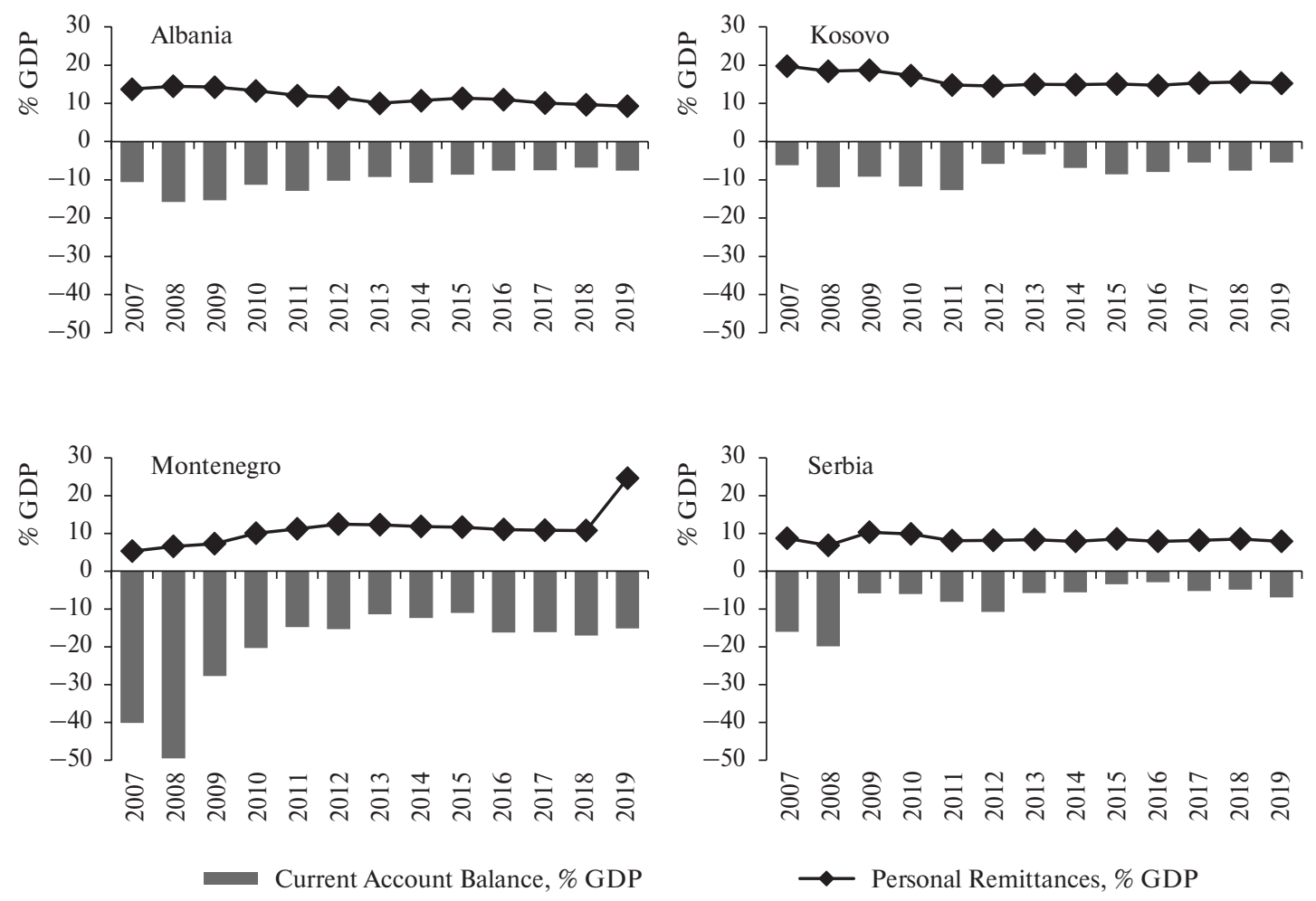

Fig. 4. Current Account Balance and the Volume of Remittances Received in Several Countries of the Balkan Peninsula, \% GDP

Source: [IMF, 2020a; World Bank, 2020i].

Both Serbia and Bosnia and Herzegovina have high shares of remittances in GDP: preliminary 2019 data indicates that the figures are at $7.9 \%$ and $10.4 \%$ respectively. In these two countries the decrease in the volume of remittances due to the lockdown may become a decisive factor for a GDP drop, aggravated by a decline in revenues from tourism, transport and logistics as well as slowdowns in exports and investments [Ralev, 2020].

All Balkan countries are characterized by high current account deficits (Fig. 4), which would most likely widen amid the slowdown of key export-oriented sectors - tourism, manufacturing and mining. Those were the direct foreign investments and remittances that supported national economies in the region during previous crises. However, taking into account peculiarities of the current recession, the volume of remittances might decrease considerably due to the rise in global unemployment and the respective decline in the real income of labour migrants and representatives of national diasporas overseas. 
The influx of foreign investments may also come under pressure so that the affected countries would be forced to tap the national financial reserves to cover their external deficits [World Bank, 2020b] or to increase international borrowing (Table 4).

Table 4. COVID-19 Emergency Financing by the IMF and the World Bank and Personal Remittances Received in Europe, \$ Millions*

\begin{tabular}{|l|c|c|c|c|}
\hline \multirow{2}{*}{ Country } & \multicolumn{2}{|c|}{ Total Financing, 2020 } & \multirow{2}{*}{ Remittances, 2019 } & Cover Ratio, *\% \\
\cline { 2 - 3 } & IMF & World Bank & & \\
\hline Albania & 191 & - & 1,455 & 13.1 \\
\hline Belarus & - & $90^{* *}$ & 1,419 & 18.2 \\
\hline Bulgaria & - & - & 2,316 & - \\
\hline Bosnia and Herzegovina & 361 & 36 & 2,192 & 18.1 \\
\hline Kosovo & 57 & 50 & 1,249 & 8.5 \\
\hline Macedonia & 192 & $90^{* *}$ & 317 & 91.5 \\
\hline Moldova & 235 & $53^{* *}$ & 1,909 & 15.3 \\
\hline Romania & - & $400^{* *}$ & 7,235 & 6.5 \\
\hline Serbia & - & 100 & 4,163 & 2.4 \\
\hline Ukraine & $5,000 * * *$ & 530 & 15,814 & 35.0 \\
\hline Montenegro & 84 & - & 1,376 & 6.1 \\
\hline
\end{tabular}

Notes. * As of 31 July 2020, ** Euro Millions.

*** 18-month Stand-By-Arrangement. The IMF transferred to Ukraine \$2.1 billion in June 2020.

Source: [IMF, 2020b; World Bank, 2020c; author's estimates].

As of 21 May 2020, the IMF provided low- and middle-income countries in Europe with grants and loans of $\$ 6.1$ billion, while the World Bank's contribution was around $\$ 1.6$ billion. The extremely high cover ratio in Macedonia (91.5\%) only testifies to the presence of significant distortions in statistical data on remittances; the actual size of remittances might be five times higher than recorded officially. ${ }^{15}$

Ukraine also has a quite high cover ratio - 35\% - as it ranks first as a receiver of remittances among the European countries in caption. The IMF approved the 18 -month $\$ 5$ billion stand-by-arrangement (SBA) programme for Ukraine after the Ukrainian Parliament passed a new law on improving specific banking regulation mechanisms [IMF, 2020c]. The SBA would cover the current account and budget deficits of Ukraine. The World Bank in its turn granted \$215 million and \$135 million in two tranches under the "Serving People, Improving Health Project" [World Bank, 2020h], which is aimed at modernization of the national health system. The EU may provide Ukraine with additional 1.2 billion euros (on top of the 0.5 billion euros already provided) under the memorandum of understanding. This financial support should be sufficient to help the Ukrainian economy overcome this year's difficulties, though the increase in the medium-term debt level remains an important issue to tackle, as its overall external debt

\footnotetext{
${ }^{15}$ Taking into account unofficial data, grants and loans from the IMF and the World Bank cover about $17 \%$ of remittance inflows.
} 
(state and state-guaranteed) exceeded $\$ 85$ billion as of 30 June 2020 [Ministry of Finance of Ukraine, n. d.].

Though Albania, Bosnia and Herzegovina, Belarus and Moldova have cover ratios between 13-18\%, while Montenegro, Romania and Kosovo have between 6\% and 9\%, this might turn out to be insufficient to prevent GDP decline in 2020.

Bulgaria remains the only country in the region that so far has not received any financial support from the IMF or the World Bank, as it is the EU that acts as the sole source of financial aid used to cover internal and external deficits. The Bulgarian government shifted funds directed from the EU on education, transport infrastructure, and environment protection toward the European regional development fund for the sake of providing support to the economy, smalland medium-enterprises, as well as the European social fund to support the unemployed.

\section{Conclusion}

The current global recession caused by the COVID-19 pandemic will have a more negative impact on the economies of the European and Central Asian countries with low and middle incomes compared with the 2008-09 crisis due to, inter alia, plummeting remittances. This will become one of the key factors to affect GDP dynamics and the current accounts of the remittance-recipient countries, leading even to a rise in poverty in some of them (such as Tajikistan, where remittances account for one fifth of household income). GDP dynamics forecasts made by the international financial organizations and national governments may be overly optimistic should the crisis continue unabated and/or the second wave of the COVID-19 pandemic leads to new lockdowns. The situation will be drastic in the Central Asian countries, Montenegro, Moldova, Kosovo and Ukraine, where the share of remittances in GDP is significant - this would require additional support for national economies and the most vulnerable population stratum (including unemployed labour migrants and their families).

Though financial aid provided by the IMF, the World Bank and other international financial institutions to Central Asian and South Caucasian countries to overcome the COVID-19 aftermath remains strong (for instance, the cover ratio in Georgia stands at 20\%), its efficiency might be hindered by the weak quality of local institutions. Not all European countries received financial support from the IMF and the World Bank, while those that are in receipt of such support may still require additional funding to stimulate consumption and rectify lockdown losses.

It is most probable that the world will not be able to immediately return to "normal life" after the removal of lockdowns, so the focus of further research studies will shift from macro to micro level factors such as unemployment of labour migrants, recurring migration, and the role of migrant networks in supporting the well-being of national diasporas abroad. The long-term emphasis should be made on broadening the geography of labour migration and changing the structure of migrant flows (such as feminization and rejuvenation). However, these questions remain outside the area of the current study and will be pursued in further research.

\section{References}

Abiad A., Arao R.M., Dagli S., Ferrarini B., Noy I., Osewe P., Pagaduan J., Park D., Platitas R. (2020) The Economic Impact of the COVID-19 Outbreak on Developing Asia. ADB Brief, Asian Development Bank. Available at: http://dx.doi.org/10.22617/BRF200096.

Adams-Prassl A., Boneva T., Golin M., Rauh C. (2020) Inequality in the Impact of the Coronavirus Shock: Evidence From Real Time Surveys. IZA Discussion Paper, Institute of Labor Economics, Deutsche Post Stif- 
tung. Available at: https://www.iza.org/publications/dp/13183/inequality-in-the-impact-of-the-coronavirusshock-evidence-from-real-time-surveys (accessed 3 September 2020).

ADB. (2020) Asian Development Outlook (ADO): What Drives Innovation in Asia? N.Y.: ABD.

Bakozoda Kh. (2019) Do 70\% naseleniya Tadzhikistana zhivut za schet perevodov trudovykh migrantov [Up to $70 \%$ of Tajikistani population are living off remittances]. Available at: https://rus.ozodi.org/a/30214025.html (accessed 2 May 2020).

Bank of Russia. (2020) Cross-border Transfers of Individuals. Available at: http://www.cbr.ru/statistics/macro_ itm/svs/\#a_71460 (accessed 13 August 2020).

Barro R.J., Ursúa J.F., Weng J. (2020) The coronavirus and the great influenza pandemic: Lessons from the "spanish flu" for the coronavirus's potential effects on mortality and economic activity. National Bureau of Economic Research. No. w26866.

Brownbridge M., Canagarajah S. (2010) Remittances and the macroeconomic impact of the global economic crisis in the Kyrgyz Republic and Tajikistan. China and Eurasia Forum Quarterly, vol. 8, no 4, pp. 3-9.

CBU. (2020) Obzor denezhno-kreditnoi politiki za I kvartal 2020 goda [The review of monetary policy in Uzbekistan, 1 quarter 2020]. Tashkent: The Central Bank of the Republic of Uzbekistan.

CCSA. (2020) How COVID-19 is changing the world: a statistical perspective, N.Y.: UNCTAD.

Chepel C., Bondarenko K. (2015) Is the External Labor Migration an Economic Growth Factor: Econometric Analysis and Policy Implications for the CIS Countries. Journal of the New Economic Association, vol. 4, no 28, pp. $142-166$.

Cohen J. (2020) Modeling Migration, Insecurity and COVID-19. Migration Letters, vol. 17, no 3, pp. 405-409.

Duarte R., Furtado I., Sousa L., Carvalho C.F.A. (2020) The 2019 novel coronavirus (2019-nCoV): novel virus, old challenges. Acta Médica Portuguesa, vol. 33, no 3, pp. 155-157.

Grigor'ev L., Brilliantova V., Pavlyushina V. (2018) Eurasian Economic Union: Achievement and Challenges of Integration. The World of New Economy, vol. 4.

Grigoryev L., Pavlyushina V., Kulaeva N., Muzychenko E. (2019) Economy of Georgia: Fragile economic stability. Voprosy Ekonomiki, vol. 10, pp. 64-84.

Grigoryev L., Pavlyushina V., Muzychenko E. (2020) The fall into 2020 recession... Voprosy Ekonomiki. vol. 5, pp. 5-24.

IMF. (2018) The Republic of Uzbekistan. External Sector Statistics Mission Report // IMF Country Report No. 20/193. Washington. Available at: https://www.imf.org/ru/Publications/CR/Issues/2020/06/09/Republic-of-Uzbekistan-Technical-Assistance-Report-External-Sector-Statistics-Mission-49495 (accessed 30 July 2020).

IMF. (2019) Montenegro: 2019 Article IV Consultation-Press Release. Washinglon, DC: IMF.

IMF. (2020a) World Economic Outlook, April 2020: The Great Lockdown. Washinglon, DC: IMF.

IMF. (2020b) Countries Receiving Emergency Financing and Debt Relief. Available at: https://www.imf.org/ en/Topics/imf-and-covid19/COVID-Lending-Tracker\#EUR (accessed 2131 May July 2020).

IOM. (2020) IOM's Displacement Tracking Matrix (DTM). Available at: https://dtm.iom.int/ (accessed 10 May 2020).

Ito K. (2017) Remittances and the Dutch Disease: Evidence from the Republic of Moldova. International Economic Journal, vol. 31, no 3, pp. 462-469.

Kartseva M., Kuznetsova P. (2020) The economic consequences of the coronavirus pandemic: which groups will suffer more in terms of loss of employment and income? Population and Economics, vol. 4, no 2, pp. 26-33.

Manasserian T. (2019) Issues of Economic Growth and Migration in Armenia in the Context of Membership in the EAEU. Dialog: politika, pravo, ekonomika, vol. 1, pp. 51-60.

MMC. (2020) Quarterly Mixed Migration Update: Latin America and the Caribbean. Available at: https://reliefweb.int/sites/reliefweb.int/files/resources/qmmu-q1-2020-lac.pdf (accessed 1031 May July 2020). 
Mukomel V. (2020) Highly skilled migrants from post-soviet states: labor mobility. Sociological Journal, vol. 26, no 2, pp. 31-59.

NBG. (2020) National Bank of Georgia. Money transfers. Available at: https://www.nbg.gov.ge/index. php?m=728\&lng=eng (accessed 10 May 2020).

NBKR. (2020) Remittances of individuals made through the money transfer system. Available at: https://www. nbkr.kg/index1.jsp?item=1785\&lang=RUS (accessed 10 May 2020).

O'Hara S., Ivlevs A., Gentile M. (2009) The Impact of Global Economic Crisis on Remittances in the Commonwealth of Independent States. Eurasian Geography and Economics, vol. 50, no 4, pp. 447-463.

Ralev R. (2020) World Bank expects Serbia's economy to shrink by 0.5\% in 2020. SeeNews. Available at: https://seenews.com/news/world-bank-expects-serbias-economy-to-shrink-by-05-in-2020-694398 (accessed 1 May 2020).

UN. (2020) COVID-19: impact could cause equivalent of 195 million job losses. UN News. Available at: https://news.un.org/en/story/2020/04/1061322 (accessed 10 May 2020).

Varshaver E. (2020) Polozheniye inostrannykh trudovykh migrantov v Rossii vo vremya pandemii koronavirusa. [The situation of foreign labor migrants in Russia during the coronavirus pandemic]. Monitoring ekonomicheskoy situatsii v Rossii: tendentsii i vyzovy sotsial'no-ekonomicheskogo razvitiya [Monitoring the economic situation in Russia: trends and challenges of socio-economic development], no 20 (122). Available at: http:// www.iep.ru/files/text/crisis_monitoring/2020_20-122_July.pdf (accessed 1 May 2020).

Vinokurov E., Levenkov A., Vasiliev G. (2020) Global Financial Safety Net in Eurasia: Accessibility of Macroeconomic Stabilization Financing in Armenia, Belarus, Kyrgyzstan, and Tajikistan. EFSD, WP/20/2.

World Bank. (2019) Migration and Remittances: Bilateral Remittance Matrix 2018.

World Bank. (2019a) Tajikistan-World Bank Group Country Partnership Framework 2019-2023. Washington, DC: World Bank. (in Russian). Available at: https://www.vsemirnyjbank.org/ru/country/tajikistan/publication/cpf-2019-2023 (accessed 1 May 2020).

World Bank. (2019b) Uzbekistan: Toward a New, More Open Economy. N.Y.: World Bank. (in Russian). Available at: https://www.worldbank.org/en/country/uzbekistan/publication/economic-update-summer-2019 (accessed 1 May 2020).

World Bank. (2020a) Migration and Development Brief. COVID-19 Crisis: Through a Migration Lens. Washington, DC: World Bank.

World Bank. (2020b) Western Balkans regular economic report no 17: The Economic and Social Impact of COVID-19. Washington, DC: World Bank.

World Bank. (2020c) World Bank Group's Operational Response to COVID-19 (coronavirus). Available at: https://www.worldbank.org/en/about/what-we-do/brief/world-bank-group-operational-response-covid19-coronavirus-projects-list (accessed 31 July 2020). 